\title{
Chemical constituents of Calotropis procera latex and ultrastructural effects on Haemonchus contortus
}

\section{Constituintes químicos do látex de Calotropis procera e efeitos ultraestruturais em Haemonchus contortus}

\author{
Géssica Soares Cavalcante1; Selene Maia de Morais ${ }^{1,2^{*}}$ (1D); Weibson Paz Pinheiro André3; \\ José Vilemar de Araújo-Filho3; Celli Rodrigues Muniz;; Letícia Oliveira da Rocha; \\ Wesley Lyeverton Correia Ribeiro6; Ana Livya Moreira Rodrigues²; Lorena Mayana Beserra de Oliveira3 \\ Claudia Maria Leal Bevilaqua3; Márcio Viana Ramos
}

\begin{abstract}
'Laboratório de Química de Produtos Naturais, Núcleo de Pesquisa em Sanidade Animal, Universidade Estadual do Ceará - UECE, Fortaleza, CE, Brasil

${ }^{2}$ Laboratório de Análises Cromatográficas e Espectroscópicas, Centro de Ciências e Tecnologia, Universidade Estadual do Ceará UECE, Fortaleza, CE, Brasil

${ }^{3}$ Laboratório de Doenças Parasitárias, Núcleo de Pesquisa em Sanidade Animal, Universidade Estadual do Ceará - UECE, Fortaleza, CE, Brasil ${ }^{4}$ Laboratório de Microscopia Eletrônica, Embrapa Agroindústria Tropical, Fortaleza, CE, Brasil

${ }^{5}$ Laboratório de Biologia Celular e Tecidual, Centro de Biociências e Biotecnologia, Universidade Estadual do Norte Fluminense - UENF, Campo dos Goytacazes, RJ, Brasil

${ }^{6}$ Departamento de Fisiologia e Farmacologia, Universidade Federal do Ceará - UFC, Fortaleza, CE, Brasil

${ }^{7}$ Laboratório de Bioquímica e Biologia de Proteínas Vegetais, Departamento de Bioquímica e Biologia Molecular, Universidade Federal do Ceará - UFC, Fortaleza, CE, Brasil
\end{abstract}

How to cite: Cavalcante GS, Morais SM, André WPP, Araújo-Filho JV, Muniz CR, Rocha LO, et al. Chemical constituents of Calotropis procera latex and ultrastructural effects on Haemonchus contortus. Braz J Vet Parasitol 2020; 29(2): e001320. https:// doi.org/10.1590/S1984-29612020045

\begin{abstract}
This study aimed to evaluate the anthelmintic and ultrastructural effects of Calotropis procera latex on Haemonchus contortus. C. procera latex was twice centrifuged at 10,000×g and dialyzed to obtain a fraction rich in proteins, named LP (latex protein), and at 3,000 rpm to obtain a fraction rich in secondary metabolites, named LNP (latex non-protein). Specimens of $H$. contortus exposed to LNP, LP and PBS in the Adult Worm Motility Test (AWMT) were submitted to scanning (SEM) and transmission (TEM) electron microscopy to verify changes in their ultrastructure. Phytochemical tests in the LNP indicated the presence of phenols, steroids, alkaloids and cardenolides. High-Performance Liquid Chromatography (HPLC) characterized the presence of the compounds gallic acid and quercetin in the LNP. The protein content in the LP was $43.1 \pm 1.1 \mathrm{mg} / \mathrm{mL}$ and $7.7 \pm 0.3 \mathrm{mg} / \mathrm{mL}$ in LNP. In AWMT, LNP and LP inhibited the motility of $100 \%$ of the nematodes, with LNP being more effective than LP and ivermectin more effective than both $(p<0.05)$. Cuticle changes were observed by SEM and TEM in nematodes treated with LP and LNP. Calotropis procera latex has anthelmintic effects against $H$. contortus, causing damage to its cuticle and other alterations in its ultrastructure.
\end{abstract}

Keywords: Anthelmintic, nematode, cuticle, latex protein, secondary metabolites.

\begin{abstract}
Resumo
Este estudo objetivou avaliar os efeitos anti-helmínticos e ultraestruturais do látex de Calotropis procera sobre Haemonchus contortus. Látex de C. procera foi centrifugado duas vezes a 10.000xg e dialisado para obter uma fração rica em proteínas, denominada proteínas do látex (LP). E centrifugado e centrifugado a 3.000 rpm, para obter uma fração rica em metabólitos secundários, denominada LNP (látex não proteico). Espécimes de $H$. contortus expostos à LNP, LP e PBS no Teste de Motilidade dos Nematoides Adultos (TMNA) foram submetidos a microscopia eletrônica de varredura (MEV) e de transmissão (MET), para verificar alterações em sua ultraestrutura. Testes fitoquímicos em LNP indicaram a presença de fenóis, esteroides, alcaloides e cardenolídeos. A presença dos compostos ácido gálico e quercetina em LNP foi caracterizada por Cromatografia Líquida de Alta Eficiência (CLAE). O conteúdo de proteínas em LP foi de $43,1 \pm 1,1 \mathrm{mg} / \mathrm{mL}$ e de $7,7 \pm 0,3 \mathrm{mg} / \mathrm{mL}$ em LNP. No TMNA, LNP e
\end{abstract}

Received January 20, 2020. Accepted April 8, 2020.

*Corresponding author: Selene Maia de Morais. E-mail: selenemaiademorais@gmail.com

This is an Open Access article distributed under the terms of the Creative Commons Attribution License, which permits unrestricted use distribution, and reproduction in any medium, provided the original work is properly cited. 
LP inibiram a motilidade de $100 \%$ dos nematoides, sendo LNP mais eficaz que LP, e a ivermectina mais eficaz que ambos $(p<0,05)$. Alterações na cutícula de nematoides tratados com LP e LNP foram observadas por MEV e MET. O látex de $C$. procera apresenta efeito anti-helmíntico sobre $H$. contortus, causando danos à sua cutícula e outras alterações em sua ultraestrutura.

Palavras-chave: Anti-helmíntico, nematoide, cutícula, proteínas do látex, metabólitos secundários.

\section{Introduction}

Haemonchus contortus is one of the main gastrointestinal nematodes affecting the global production of sheep and goats and is considered the most pathogenic and prevalent in tropical and subtropical regions (Niciura et al., 2019; Santos et al., 2017). Infections by gastrointestinal nematodes can cause economic losses by reducing the productivity and fertility of herds, involving morbidity, weight loss and growth retardation, as well as mortality in cases of severe infection (Alowanou et al., 2019).

The resistance of gastrointestinal nematodes in small ruminants to commercially available anthelmintics is widely disseminated, making it necessary to adopt alternative measures to control these infections (Elandalousi et al., 2013; Ribeiro et al., 2015). Among the alternatives, the investigation of medicinal plants with anthelmintic potential has received much attention (Acharya et al., 2014; Hoste \& Torres-Acosta, 2011).

The therapeutic properties of many plants traditionally used for medicinal purposes have been scientifically proven (Belemlilga et al., 2016; Macedo et al., 2012). The use of these plants has advantages, such as a low cost, biodegradability and a lack of ecological harm (Zhu et al., 2013). In addition, medicinal plants are also sources of bioactive compounds derived from primary and secondary metabolism, enabling the development of new drugs (Ribeiro et al., 2013).

In the validation of the anthelmintic properties of medicinal plants, $H$. contortus has been the target of several in vitro studies that used immature stages, such as eggs and larvae, or the adult parasite, as well as in vivo studies using sheep or goats that were naturally or experimentally infected (Cavalcante et al., 2016; Ribeiro et al., 2017). Associated with these tests, analyses have been proposed to understand the effect of phytotherapeutics or compounds derived from medicinal plants, such as the analysis of changes in the structure of eggs, larvae or adult nematodes by scanning or transmission electron microscopy (Araújo-Filho et al., 2018; Brunet et al., 2011; Cortes-Morales et al., 2019). Different microscopic techniques allow for verifying changes in the ultrastructure of the parasites and identifying their potential target structures (Sant'anna et al., 2013).

Calotropis procera (Aiton) W.T. Aiton, belonging to the family Apocynaceae, is a shrub that produces latex and is native to India and Africa, where it has traditionally been used for various medicinal purposes, including for the treatment of animal worms (Iqbal et al., 2005). Latex plays an important defence role in plants, acting against herbivorous insects, nematodes and phytopathogenic fungi (Ramos et al., 2019; Upadhyay et al., 2011).

The latex of $C$. procera has a wide pharmacological profile and has been investigated regarding its anthelmintic activity (Al-Qarawi et al., 2001; Cavalcante et al., 2016). In contrast, some components of this fluid cause toxicity in small ruminants (El Sheikh et al., 1991; Mahmoud et al., 1979). Some studies suggest that the insoluble fraction of C. procera latex is associated with the toxic effects of this fluid (Dewan et al., 2000; Kumar \& Shivkar, 2004). In this respect, it is necessary to purify the compounds responsible for the therapeutic effect to separate them from those causing toxicity, as proposed also in this work.

Thus, this study aimed to evaluate the in vitro anthelmintic effect of two fractions (the soluble fraction and protein fraction) of $C$. procera latex against $H$. contortus and to verify the induction of changes in the morphology and ultrastructure of $H$. contortus exposed to these fractions.

\section{Materials and Methods}

\section{Latex collection and purification}

Specimens of C. procera, occurring naturally in two locations (S 3047'25.82484" W 38³3'10.92672 and S $3^{\circ} 45^{\prime} 18.16668^{\prime \prime}$ W $\left.38^{\circ} 33^{\prime} 21.86964\right)$ within the municipality of Fortaleza, Ceará state, Brazil, were identified and deposited in the Prisco Bezerra Herbarium of Ceará Federal University under registration number 58425. The latex of $C$. procera was obtained by breaking the vegetative apex and collecting latex in tubes containing the same proportion of distilled water (ratio of 1:1 v/v). C. procera latex was centrifuged at 3,000 rpm for $20 \mathrm{~min}$, the 
precipitate (insoluble fraction) was discharged and the supernatant was frozen for subsequent lyophilization, from which a product rich in secondary metabolites was obtained and named LNP (latex non-protein fraction)

A fraction rich in protein (LP) was obtained according to Ramos et al. (2013). First, C. procera latex was centrifuged at $10,000 \times \mathrm{g}$ and $4^{\circ} \mathrm{C}$, for $20 \mathrm{~min}$. The supernatant was then dialyzed (molecular weight cut off of 8,000 Da) for $60 \mathrm{~h}$ in distilled water $\left(4^{\circ} \mathrm{C}\right)$ for elimination of small molecules, such as secondary metabolites, followed by a second centrifugation step $\left(10,000 \times g, 4^{\circ} \mathrm{C}, 20 \mathrm{~min}\right)$. The supernatant was then lyophilized to produce the LP.

\section{Chemical and biochemical analysis}

To identify the secondary metabolite classes, present in the LNP, phytochemical tests were performed with this fraction. Phenolic compounds present in the LNP were investigated by high-performance liquid chromatography. The soluble protein content was measured in both the LNP and LP. These assays are described below.

\section{Phytochemical tests}

Phytochemical analysis was performed according to the methodology of Matos (1988). Briefly, tests were carried out with specific reagents which form coloured compounds or precipitates as positive indication of determined class of secondary metabolite. The following classes were investigated:

Phenols, tannins and anthocyanins-an aliquot of the LNP (30 mg) was solubilized in $15 \mathrm{~mL} 70 \%$ ethanol and distributed in 3 test tubes. Two drops of ferric chloride solution were added to a tube, and colour changes between blue and green indicated the presence of phenols, and precipitate formation indicated the presence of tannins. The sample in tube 2 was acidified $(\mathrm{pH} 3)$ with hydrochloric acid solution $(0.1 \mathrm{M})$, and in tube 3, it was alkalized $(\mathrm{pH} 8.5$ and 11$)$ with sodium hydroxide solution $(0.1 \mathrm{M})$. Then, tubes 2 and 3 were heated. The different colour changes indicated the presence of various constituents.

Steroids and triterpenes-an aliquot of the LNP $(10 \mathrm{mg})$ was solubilized in $5 \mathrm{~mL}$ chloroform and filtered with anhydrous sodium sulfate. Then, $1 \mathrm{~mL}$ acetic anhydride and 3 drops sulfuric acid were added. Blue-to-green coloration indicated the presence of steroids, and brown-to-red coloration indicated the presence of triterpenes;

Saponins-an aliquot of the LNP (20 mg) was solubilized in distilled water $(5 \mathrm{~mL})$ and shaken vigorously. A permanent foaming is indicative of saponin's presence;

Alkaloids-an aliquot of the LNP (20 mg) was solubilized in $0.1 \mathrm{M}$ hydrochloric acid $(6 \mathrm{~mL})$, filtered and distributed between 2 test tubes; then, three drops of Draggendorf or Mayer reagents were added. Precipitate formation indicated the presence of alkaloids.

The presence of cardiac glycosides was investigated by Keller Kelliani's test (Hassan et al., 2017). An aliquot of the LNP (20 mg) was solubilized in $5 \mathrm{~mL}$ distilled water, and $2 \mathrm{~mL}$ glacial acetic acid and a drop of ferric chloride solution were added. Then, $1 \mathrm{~mL}$ sulfuric acid was added. A brown ring at the interface indicated the presence of cardenolides.

\section{High-performance liquid chromatography}

An aliquot of the LNP $(40 \mathrm{mg} / \mathrm{mL})$ solubilized in HPLC-grade methanol was submitted to HPLC-DAD via a Shimadzu Prominence HPLC system equipped with an auto-sampler (SIL-20A) (Shimadzu, Kyoto, Japan), Shimadzu LC-20AD reciprocating pumps connected to a DGU 20A5 degasser with a CBM 20A integrator, an SPD-M20A diode array detector, and LC solution 1.22 SP1 software. A reversed-phase Shim-pack CLC-ODS (M) column (250 × $4.6 \mathrm{~mm}$, $5 \mu \mathrm{m})$ was used.

Separation was performed with a linear gradient as previously described, with some modifications (Silva et al., 2011). Acetonitrile (C) and Milli-Q water ( $\mathrm{pH}$ 2.8) (D) were used as the mobile phases with the following gradient elution programme: 0-15 min, isocratic elution with C:D $(20: 80 \mathrm{v} / \mathrm{v}) ; 17-25 \mathrm{~min}$, linear change to C:D $(40: 60 \mathrm{v} / \mathrm{v})$; and 25-40 min, isocratic elution with C:D (20:80 v/v). The flow rate was $1.0 \mathrm{~mL} / \mathrm{min}$, the injection volume was $20 \mu \mathrm{L}$, and the detection wavelength was $350 \mathrm{~nm}$. The LNP sample was analysed in triplicate.

Chromatographic peaks were confirmed by comparing the retention time $\left(t_{R}\right)$ and DAD spectra with those of reference standards. The reference standards were gallic acid and quercetin. Calibration curve for galic acid was $y=3.10^{-8} x-0.0061(r=0.9997)$; quercetin $y=2.10^{-8} x-0.0001(r=0.999)$. Gallic acid was obtained from Sigma Chemical 
Co. (St. Louis, MO, USA), and quercetin was obtained by acid hydrolysis of rutin with $3 \%$ sulfuric acid, according Vila-Nova et al. (2012).

\section{Protein dosage}

The content of soluble proteins in LNP and LP was measured using the colorimetric method, as described by Bradford (1976). For this purpose, $2.5 \mathrm{~mL}$ of Bradford reagent was added to $100 \mu \mathrm{L}$ of the LNP or LP in distilled water $(1 \mathrm{mg} / \mathrm{mL})$ and slightly shaken. The process was performed in triplicate. After $10 \mathrm{~min}$, absorbance readings were performed at $595 \mathrm{~nm}$. The protein content was estimated using a calibration curve of bovine serum albumin $(B S A)$ as the standard reference.

\section{Animal welfare}

The procedures using sheep were approved by the Ethics Committee for Animal Use of Ceará State University (Protocol No. 7700820/2016).

\section{Adult Worm Motility Test (AWMT)}

This test was performed according to André et al. (2016). Adult parasites were obtained from an experimentally infected sheep harbouring a benzimidazole-resistant isolate of $H$. contortus. The level of infection was monitored using the McMaster technique with modifications (Ueno \& Gonçalves, 1998), and the sheep were euthanized approximately 40 days after infection, exhibiting 20,000 eggs per gram (EPG). Immediately after slaughter, the abomasum was removed and briefly washed with phosphate buffered saline (PBS) at $37^{\circ} \mathrm{C}$; then, the nematodes were collected from the mucosa.

The parasites, three females/well, were placed as soon as possible in 24-well plates containing PBS with 4\% antibiotics (penicillin and streptomycin) and placed in a $\mathrm{CO}_{2}$ incubator $(5 \%)$ at $37^{\circ} \mathrm{C}$ for one hour. Then, different concentrations, determined in a preliminary test, of the $\operatorname{LNP}(1,0.5,0.25,0.12$ and $0.062 \mathrm{mg} / \mathrm{mL})$ and $\operatorname{LP}(1.6,0.8$, $0.4,0.2$ and $0.1 \mathrm{mg} / \mathrm{mL})$ diluted in PBS were added. Ivermectin $(0.1 \mathrm{mg} / \mathrm{mL})$ and PBS with antibiotics were used as positive and negative controls, respectively. Eight replicates were performed for each treatment and control. The motility of adult nematodes was verified by careful observation under a stereomicroscope after 3, 6, 12 and $24 \mathrm{~h}$.

At the end of the test, twelve parasites were collected from each of the highest tested concentrations of the LNP $(1 \mathrm{mg} / \mathrm{mL})$ and LP $(1.6 \mathrm{mg} / \mathrm{mL})$ and from the negative control (PBS). The nematodes were fixed and subsequently subjected to scanning and transmission electron microscopy for analysis of ultrastructural changes. Nematodes treated with the LNP and LP were compared to nematodes not treated with C. procera latex fractions (negative control).

\section{Scanning Electron Microscopy (SEM)}

Haemonchus contortus obtained from the AWMT were fixed in $2.5 \%$ glutaraldehyde solution in $0.1 \mathrm{M}$ sodium cacodylate buffer for a minimum period of $72 \mathrm{~h}$. Subsequently, three washes were performed with PBS, followed by post-fixation with osmium tetroxide solution (1\%) for $1 \mathrm{~h}$ for greater contrast of the material. Then, the parasites were washed three times with distilled water $(10 \mathrm{~min})$ and dehydrated in a gradual ethanol series $(10,20,30,60,70,80,90$ and 100\%, 5 min each). The ethanol was then replaced with liquid carbon dioxide, and the samples were dried using an EMS 850 critical-point drying apparatus. The samples were mounted on stubs, coated with gold-palladium and observed with a Zeiss DSM-940A scanning electron microscope at an acceleration voltage of $15 \mathrm{kV}$. Alterations were observed in the morphology of the treated and control group parasites.

\section{Transmission Electron Microscopy (TEM)}

Haemonchus contortus obtained from the AWMT were fixed in $2.5 \%$ glutaraldehyde, $4 \%$ paraformaldehyde and $0.1 \mathrm{M}$ sodium cacodylate buffer, $\mathrm{pH} 7.1$, for $48 \mathrm{~h}$. The samples were then washed three times in sodium cacodylate buffer, post-fixed in $1 \%$ osmium tetroxide solution for $1 \mathrm{~h}$ and rinsed again with the same buffer. The samples were dehydrated in an increasing acetone series (30,40,50, 70, 90 and 100\%, for $1 \mathrm{~h}$ each) and were encased in Spurr resin and polymerized at $60^{\circ} \mathrm{C}$. Ultra-thin sections of $70 \mathrm{~nm}$ were obtained and collected in 400 mesh copper grids and counterstained with $1 \%$ uranyl acetate and $5 \%$ lead citrate. The samples were then analysed with 
a JEOL 1400 Plus transmission electronic microscope at $60 \mathrm{kV}$. Changes were observed in the ultrastructure of the treated parasites compared to that of the parasites of the control group.

\section{Statistical Analysis}

In the AWMT, for each observed time $(3,6,12$ and $24 \mathrm{~h})$, the percentage of motility inhibition of replicates of each treatment (the LNP, LP, Ivermectin and PBS groups) was calculated according to the following Equation 1:

$$
\text { Motility inhibition }(\%)=\frac{\text { number of motionless parasites }}{\text { total number of parasites per well }} \times 100
$$

These data were submitted to the Shapiro-Wilk test for normality analysis ( $p>0.05)$, to be adequate to the criteria for using the ANOVA. Then, were submitted to two-way ANOVA and compared by the Bonferroni test, with a 5\% significance level $(p<0.05)$, using GraphPad Prism 5.01 software. The results are expressed as the mean \pm standard deviation. The effective concentration to inhibit the motility of $50 \%$ of the adult nematodes $\left(E_{50}\right)$ was determined by probit regression using SPSS 22 for Windows, according to Araújo-Filho et al. (2019). The $E_{50}$ was measured at all times evaluated in the test $(3,6,12$ and $24 \mathrm{~h})$.

\section{Results}

The latex of $C$. procera contained $87.3 \pm 1.6 \%$ water and $12.7 \pm 1.6 \%$ corresponded to dry mass. Based on the dry mass of the $C$. procera latex, the LNP and LP presented yields of $48.3 \pm 1.3 \%$ and $5.8 \pm 0.5 \%$, respectively. The protein content, estimated by the Bradford method (1976), was $43.1 \pm 1.1 \mathrm{mg} / \mathrm{mL}$ in the $\mathrm{LP}$ and $7.7 \pm 0.3 \mathrm{mg} / \mathrm{mL}$ in the LNP. Secondary metabolites were separated from the LP by dialysis, while phytochemical tests indicated the presence of secondary metabolites, such as phenols, steroids, alkaloids and cardiac glycosides, in the LNP. The presence of gallic acid and quercetin was detected by HPLC in the LNP (Figure 1), where the retention times and UV-Vis spectrum of the compounds were similar to those of the analysed standards.

In relation to AWMT, the motility of $H$. contortus submitted to LNP and LP was shown in Figure 2 , while the effect of LNP and LP on the inhibition of motility was shown in Table 1 . The highest concentration of LNP $(1 \mathrm{mg} / \mathrm{mL})$<smiles>O=C(O)c1cc(O)c(O)c(O)c1</smiles>

(Gallic acid)<smiles>O=c1c(O)c(-c2ccc(O)c(O)c2)oc2cc(O)cc(O)c12</smiles>

(Quercetin)

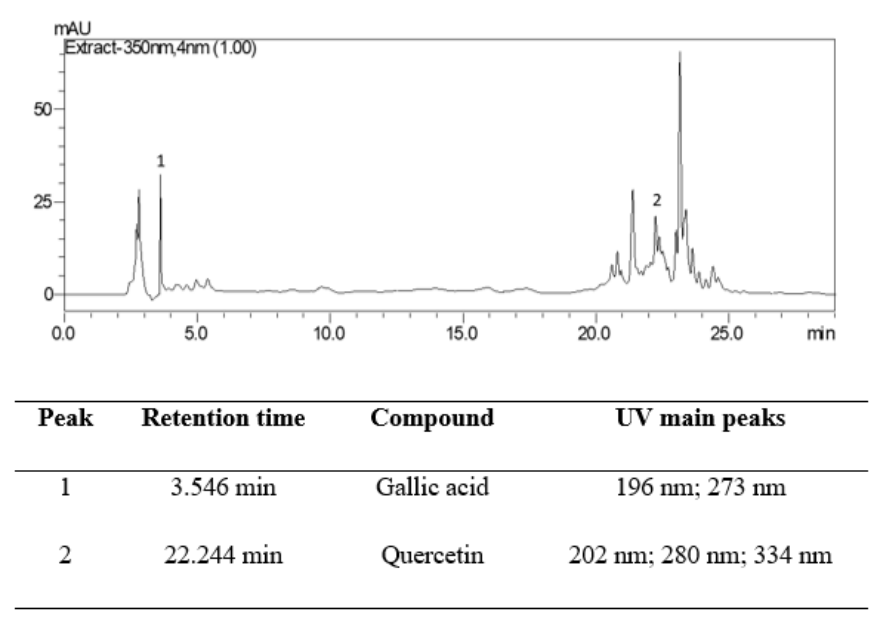

Figure 1. Representative high-performance liquid chromatograph of the non-protein fraction (LNP) of Calotropis procera latex. UV: Ultraviolet. 
inhibited the motility of $100 \pm 0.0 \%$ of parasites after $6 \mathrm{~h}$ of contact, while the highest concentration of LP $(1.6 \mathrm{mg} / \mathrm{mL})$ inhibited the motility of $95.8 \pm 11.8 \%$ of parasites only after $12 \mathrm{~h}$ of exposure. Ivermectin $(0.1 \mathrm{mg} / \mathrm{mL})$ inhibited the motility of $100 \pm 0.0 \%$ of parasites at the first observed time (3h), differing statistically from all LNP or LP concentrations tested at that time.

(a)

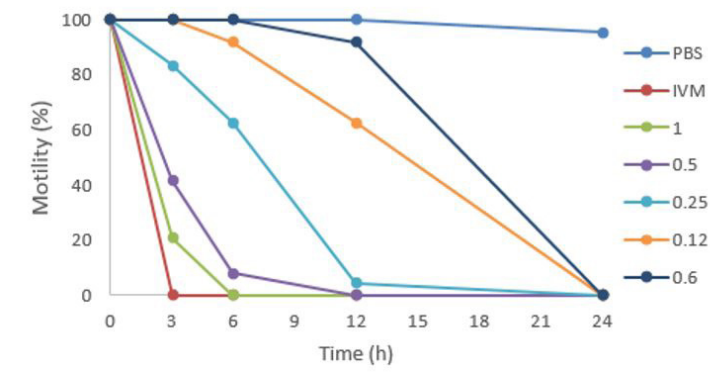

(b)

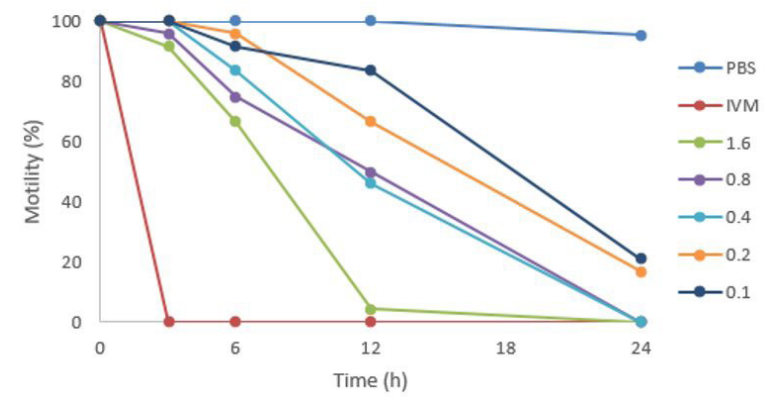

Figure 2. Motility of Haemonchus contortus (\%) exposed to the Calotropis procera latex fractions: non-protein fraction-LNP (graph a - concentrations from $0.62,0.12,0.25,0.5$ and $1 \mathrm{mg} / \mathrm{mL}$ ) and protein fraction-LP (graph b - concentrations from 0.1, 0.2, $0.4,0.8$ and $1.6 \mathrm{mg} / \mathrm{mL}$ ). Phosphate buffered saline (PBS) and $0.1 \mathrm{mg} / \mathrm{mL}$ ivermectin (IVM) were used as negative and positive controls, respectively.

Table 1. Mean efficacy (percentage \pm standard deviation) of non-protein (LNP) and protein (LP) fraction of Calotropis procera latex, ivermectin and phosphate buffered saline (PBS) on motility inhibition of Haemonchus contortus. The effective concentration to inhibit the motility of $50 \%\left(\mathrm{EC}_{50}\right)$ of the adult worms submitted to LNP and LP was obtained for times 3,6 and $12 \mathrm{~h}$.

\begin{tabular}{|c|c|c|c|c|c|}
\hline & $\begin{array}{l}\text { Concentration } \\
(\mathrm{mg} / \mathrm{mL})\end{array}$ & $3 h$ & $6 h$ & $12 \mathrm{~h}$ & $24 h$ \\
\hline & 1.0 & $79.2 \pm 17.2^{\text {в }}$ & $100.0 \pm 0.0^{A}$ & $100.0 \pm 0.0^{A}$ & $100.0 \pm 0.0^{\mathrm{A}}$ \\
\hline \multirow[t]{6}{*}{ LNP } & 0.5 & $58.3 \pm 29.5^{c}$ & $91.7 \pm 15.4^{\mathrm{A}}$ & $100.0 \pm 0.0^{\mathrm{A}}$ & $100.0 \pm 0.0^{A}$ \\
\hline & 0.25 & $16.7 \pm 17.8^{D}$ & $37.5 \pm 11.8^{\mathrm{B}}$ & $95.8 \pm 11.8^{A}$ & $100.0 \pm 0.0^{A}$ \\
\hline & 0.12 & $0.0 \pm 0.0^{D}$ & $8.3 \pm 15.4^{c}$ & $37.5 \pm 11.8^{\mathrm{B}}$ & $100.0 \pm 0.0^{\mathrm{A}}$ \\
\hline & 0.06 & $0.0 \pm 0.0^{D}$ & $0.0 \pm 0.0^{c}$ & $8.3 \pm 15.4^{c}$ & $100.0 \pm 0.0^{\mathrm{A}}$ \\
\hline & $E C_{50}(m g / m L)$ & 0.50 & 0.27 & 0.13 & - \\
\hline & 1.6 & $8.3 \pm 15.4^{D}$ & $33.3 \pm 25.2^{\mathrm{B}}$ & $95.8 \pm 11.8^{A}$ & $100.0 \pm 0.0^{A}$ \\
\hline \multirow[t]{5}{*}{ LP } & 0.8 & $4.2 \pm 11.8^{D}$ & $25.0 \pm 23.6^{B C}$ & $50.0 \pm 25.2^{\mathrm{B}}$ & $100.0 \pm 0.0^{A}$ \\
\hline & 0.4 & $0.0 \pm 0.0^{D}$ & $16.7 \pm 17.8^{\mathrm{BC}}$ & $54.2 \pm 35.4^{\mathrm{B}}$ & $100.0 \pm 0.0^{A}$ \\
\hline & 0.2 & $0.0 \pm 0.0^{D}$ & $4.2 \pm 11.8^{c}$ & $33.3 \pm 25.2^{\mathrm{BC}}$ & $83.3 \pm 25.2^{B}$ \\
\hline & 0.1 & $0.0 \pm 0.0^{D}$ & $8.3 \pm 15.4^{c}$ & $16.7 \pm 17.8^{c}$ & $79.2 \pm 17.2^{B}$ \\
\hline & $E C_{50}(m g / m L)$ & 6.9 & 4.4 & 0.4 & - \\
\hline PBS & - & $0.0 \pm 0.0^{D}$ & $0.0 \pm 0.0^{c}$ & $0.0 \pm 0.0^{c}$ & $4.2 \pm 11.8^{c}$ \\
\hline Ivermectin & 0.1 & $100.0 \pm 0.0^{\mathrm{A}}$ & $100.0 \pm 0.0^{A}$ & $100.0 \pm 0.0^{A}$ & $100.0 \pm 0.0^{\mathrm{A}}$ \\
\hline
\end{tabular}

Capital letters compare means in the columns. Different letters indicate significantly different values $(p<0.05)$. 
The interactions between the factors (times and treatments) were statistically significant, with the time and treatment factors accounting for $32.6 \%$ and $43.5 \%$ of the total variation, respectively. The LNP and LP presented dose-dependent effects at $3 \mathrm{~h}, 6 \mathrm{~h}$ and $12 \mathrm{~h}$, being possible to calculate their $\mathrm{EC}_{50}$ at each of these times (Table 1). For the $24 \mathrm{~h}$ period, it was not possible to obtain an $\mathrm{EC}_{50^{\prime}}$ since all LNP concentrations and the three highest concentrations of LP inhibited the motility of $100 \pm 0.0 \%$ of the nematodes. On the other hand, in the negative control group, only $4.17 \pm 11.8 \%$ of the parasites lost their motility only at the last observed time ( $24 \mathrm{~h}$ ).

In the SEM micrographs, changes were observed along the cuticle of $H$. contortus females exposed in vitro to the LNP and LP, including in the cephalic region and vulvar appendage (Figure 3). The alterations consisted of wrinkling of the cuticle, blister formation along the cuticle, and, in the case of the LP, deposition of material in the vulvar region. The vulvar appendage of $H$. contortus females was of the linguiform type (Figure 3), and in the LNP (B3)
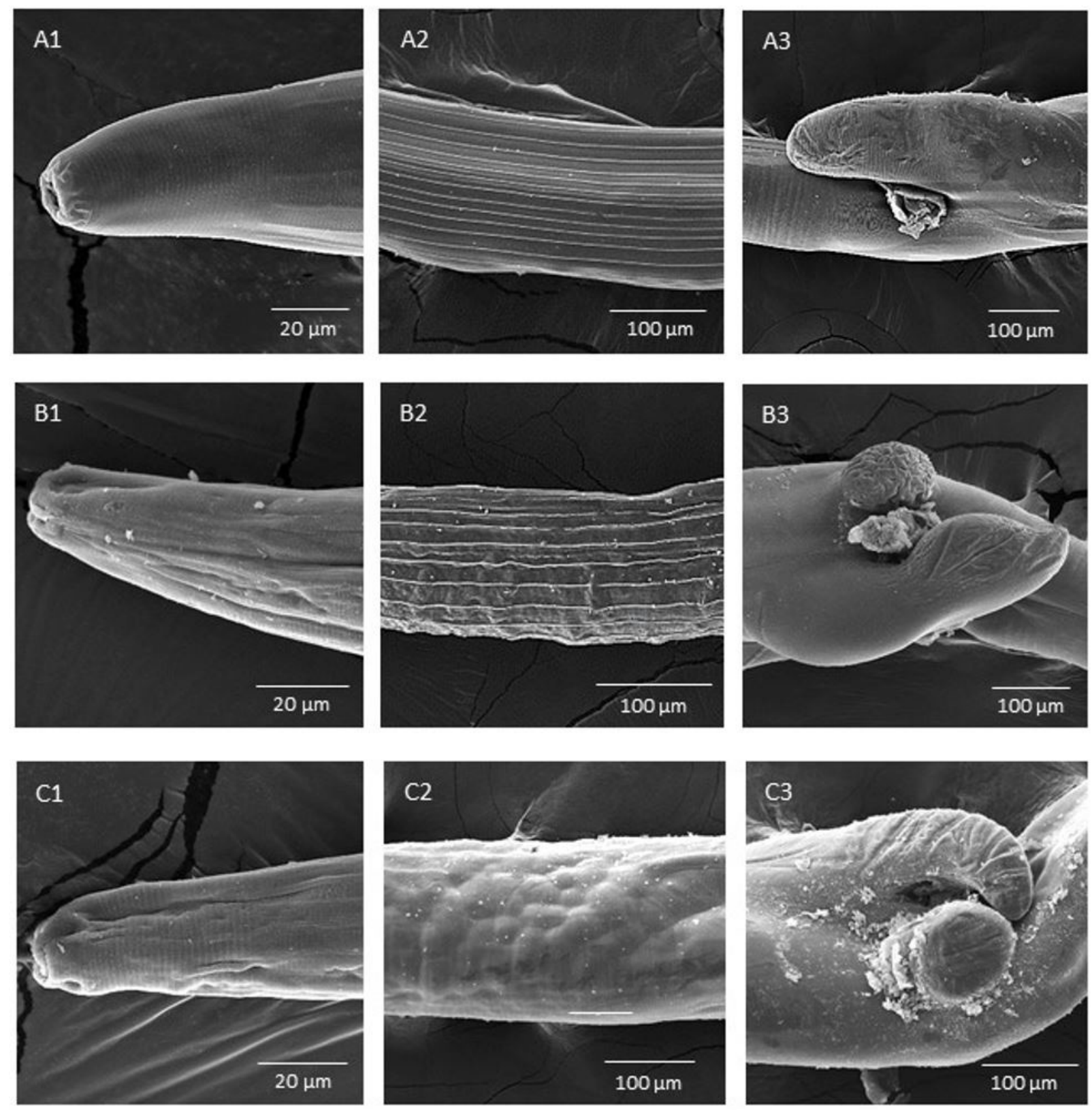

Figure 3. Haemonchus contortus females submitted in vitro to Phosphate buffered saline (PBS: A1, A2, and A3) and Calotropis procera latex fractions: $1 \mathrm{mg} / \mathrm{mL}$ of non-protein fraction (LNP: B1, B2, and B3) and $1.6 \mathrm{mg} / \mathrm{mL}$ of protein fraction (LP: C1, C2, and C3), and analysed by scanning electron microscopy (SEM). A1, B1 and C1: encephalic region; A2, B2 and C2: median portion; A3, B3 and C3: vulvar appendage. The wrinkling and formation of bubbles in the cuticle of nematodes exposed to the LNP and LP were observed. There was marked deposition of material in C3. 

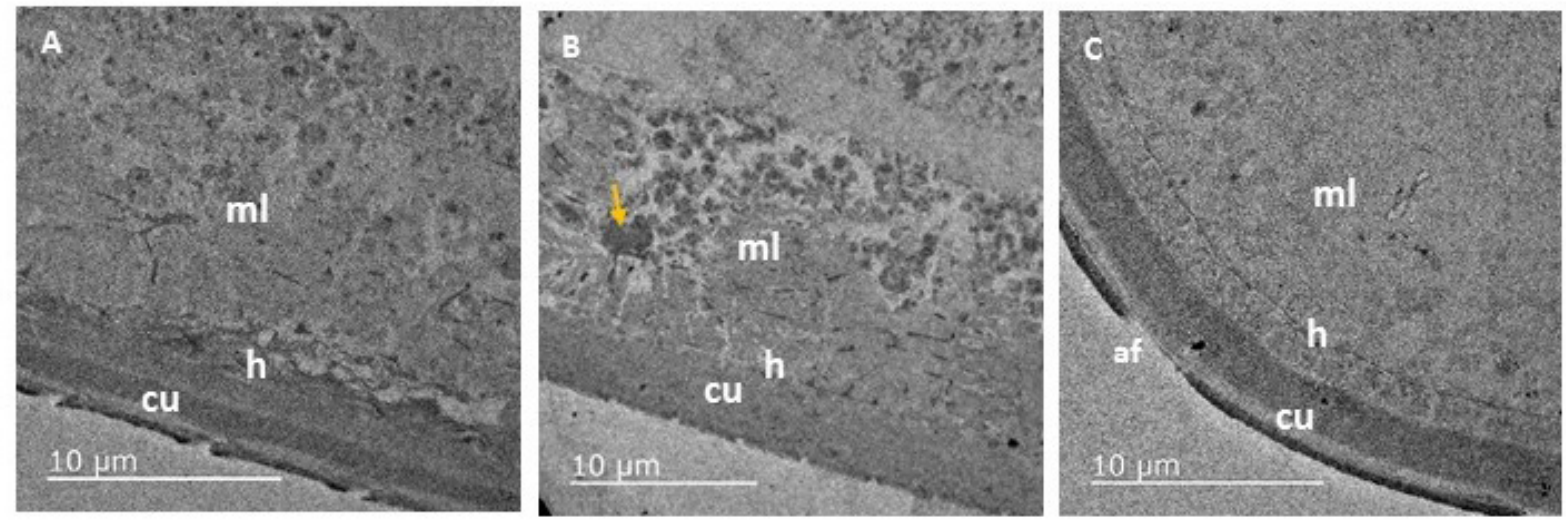

Figure 4. Haemonchus contortus females submitted in vitro to water (negative control, A) and Calotropis procera latex fractions: $1 \mathrm{mg} / \mathrm{mL}$ of non-protein fraction (LNP, B) and $1.6 \mathrm{mg} / \mathrm{mL}$ of protein fraction (LP, C), and analyzed by transmission electron microscopy (TEM). There was disorganization of cuticle layers and degradation of the muscular layer (A, B). af: annular furrow; cu: cuticle; ml: muscular layer; h: hypodermis. The arrow points to an electron-dense body.

and LP (C3) treated females, the presence of a lateral button was also observed. The set of longitudinal cuticular ridges (synlophe) of nematodes in the negative control group appeared well preserved.

The TEM results are shown in Figure 4. It was possible to observe disorganization of the cuticle of the nematodes treated in vitro with the LNP and LP. There was also degradation of the muscular layer of the parasites treated with the LNP, especially in the region with abundant mitochondria, also with the occurrence of electron-dense bodies. The muscular layers of the parasites treated with LP were entirely degraded, making it impossible to distinguish myofibrils and mitochondria in this tissue.

\section{Discussion}

In the present study, insoluble material of latex was removed via centrifugation to concentrate the bioactive molecules in the LNP. The concentration of total proteins in the LNP was 5.6 times lower than that in the LP, which corresponded to a purified fraction of the proteins of $C$. procera latex. The LP of $C$. procera was composed of basic proteins, with molecular masses ranging from 5 to $95 \mathrm{kDa}$, and presented proteolytic potential (Freitas et al., 2007). Proteins, such as cysteine, chitinases, peroxidases and osmotin have been identified in C. procera latex, including proceraine, proceraine B, calotropin DI and DII, calotropaine, calotropaine FI and FII, and CpOsm (Freitas et al., 2011; Ranjit et al., 2012; Singh et al., 2010).

Plant latex contains a wide range of specialized metabolites that are partially responsible for various activities, such as antibacterial, antifungal and anthelmintic activities; among these compounds are terpenoids, cardenolides, alkaloids and phenolics (Abarca et al., 2019). In C. procera latex, several metabolites have been identified, including cardenolides, alkaloids, steroids and phenols (Chundattu et al., 2016; Mohamed et al., 2015; Ranjit et al., 2012), which were also found in the present investigation. According to Murti et al. (2015), polyphenolic compounds show anthelmintic activity. Among these compounds, gallic acid and quercetin have already been reported in extracts of C. procera aerial parts (Khasawneh et al., 2011). Patel et al. (2015) and Kore et al. (2018) report significant activity of gallic acid and quercetin against Pheretima postuma, respectively. The $P$. posthuma (Annelida) is an earthworm used as a suitable model for screening of anthelmintic drug (Kore et al., 2018).

The latex of other plants, such Carica papaya and Ficus spp., has shown anthelmintic activity, and the proteins, especially cysteine peptidases, present in these fluids have been identified as responsible for the observed effect (Amorin et al., 1999; behnke et al., 2008). In this study, both the LNP and LP had promising anthelmintic effects on adult $H$. contortus, inhibiting the motility of parasites at low concentrations and in a short period of time. The results obtained were superior, for example, to the decoction of Saba senegalensis (Apocynaceae) leaves and an extract rich in hydrolysable tannins, which presented $\mathrm{EC}_{50}$ values of 6.79 and $3.54 \mathrm{mg} / \mathrm{mL}$ after $24 \mathrm{~h}$ of exposure, respectively (Acevedo-Ramírez et al., 2019; Belemlilga et al., 2016). However, the LNP and LP were not as effective as ivermectin (Table 1). The LNP was more effective than LP and had an $\mathrm{EC}_{50}$ lower than LP at all times tested (Table 1). Thus, it was possible that the effect of the LNP was caused by synergistic action among its compounds, including the proteases that were also present in the LP. 
In vitro tests are used for preliminary investigation of the anthelmintic potential of natural products or isolated compounds, and tests using adult nematodes are considered more reliable than those using developing stages, such as eggs and larvae (André et al., 2016; Ribeiro et al., 2017). In addition, SEM and TEM analysis of the parasites submitted to these tests may present alterations that demonstrate the loss of homeostasis associated with the observed anthelmintic effect and may indicate the type of action of the bioactive compounds on the parasites (Behnke et al., 2008; Brunet et al., 2011; Martínez-Ortíz-De-Montellano et al., 2013).

In the present study, SEM allowed for the observation of damage in the $H$. contortus cuticle exposed to the LNP and LP, such as blistering and longitudinal and transverse wrinkling along the cuticle and on the vulvar appendage of the females. This damage was also verified in the $H$. contortus cuticle exposed to other plant-derived compounds, such as the monoterpenes carvacrol, acetylated carvacrol and thymol (André et al., 2016, 2017). Similarly, extracts rich in tannins, such as a decoction of Spigelia anthelmia (Ribeiro et al., 2017), an extract of hydrolysable tannins obtained from Castanea sativa (Acevedo-Ramírez et al., 2019) and extracts from leaves of Onobrychis viciifolia or Lysiloma latisiliquum (Martínez-Ortíz-De-Montellano et al., 2013), caused damage to the $H$. contortus cuticle similar to those observed in this study.

The presence of aggregated material in the vulvar region, as observed in the parasites treated in vitro with the LP, has already been reported for extracts rich in tannins, having been observed around the buccal capsule and in the anus of $H$. contortus, in addition to the vulvar region (Martínez-Ortíz-De-Montellano et al., 2013). These authors stated that the presence of aggregates in the vulvar region may affect the reproductive function of the nematodes due to mechanical obstruction of egg production or expulsion.

It is possible that changes observed in the cuticle of the LNP-treated nematodes were induced mainly by the cysteine peptidases present in the extract, since nematodes treated with the purified protein fraction (LP) showed more intense changes in the cuticle than those treated with the LNP. Cysteine peptidases from other plants induced cross-sectional wrinkling of the cuticle of Heligmosomoides bakeri, a rodent nematode, after 30 min of exposure (Behnke et al., 2008). It was also verified that cysteine peptidases were mainly responsible for the effect of papaya latex (Carica papaya) on the motility of $\mathrm{H}$. bakeri in tests using cysteine inhibitors. In addition, $H$. contortus exposed to the ethyl acetate extract of $C$. procera latex exhibited inhibited motility but showed no changes in their cuticle (Cavalcante et al., 2016).

In TEM, the changes observed between the nematodes treated in vitro with the LNP and LP and those in the control group were disorganization of the cuticle, muscle layer degradation, especially in the region with abundant mitochondria, and the presence of electron-dense bodies. These changes have been observed in studies evaluating the effect of commercial anthelmintics or compounds with anthelmintic potential, with electron-dense bodies commonly being found in degraded tissues, as well as observed negative effects on mitochondria related to a decline in energy production (Brunet et al., 2011; Jiao et al., 2019; Rothwell \& Sangster, 1996; Sant'anna et al., 2013).

The cuticle of nematodes consisted of three basic layers: the cortex, matrix layer and basal layer (fibre layer). These layers can be subdivided (Anya, 1966). In the nematodes treated with the LNP and LP, it was not possible to distinguish the basal layers, indicating the disorganization of these structures. The cuticle is a crucial structure for nematode development and survival (Page et al., 2014). In addition, the cuticle of nematodes is a potential site for drug uptake, where the pores present in the collagen matrix control the passage of molecules depending on their physicochemical properties, especially lipophilicity (Lanusse et al., 2018; Mottier et al., 2003, 2006). The entry and accumulation of anthelmintic drugs in parasites are determinants to achieve optimal efficacy, and the transcuticular route is the main entry path of anthelmintic drugs in parasites (Lanusse et al., 2018).

\section{Conclusion}

In conclusion, the latex of $C$. procera contained bioactive constituents with potential anthelmintic activity, such as proteins and compounds derived from secondary metabolism. The fractions of $C$. procera latex caused severe damage to the cuticle of $H$. contortus, as well as ultrastructural disorganization. This information corroborates the use of $C$. procera in traditional medicine, but further studies are needed to assess the in vivo anthelmintic efficacy and toxicological safety of latex of this species as well as its bioactive compounds. 


\section{Acknowledgements}

We would like to thank CNPq for financial support (407665/2013-7), CAPES for a scholarship, Embrapa Tropical Agroindustry for SEM analysis and Beatriz Ferreira for technical help. The TEM analyses were made possible by the use of the JEOL 1400 Plus TEM multiuser equipment facility (FAPERJ grant number E-26/110.040/2013). Dr. Morais (407665/2013) and Dr. Bevilaqua (303018/2013-5) were supported by research fellowships from CNPq.

\section{References}

Abarca LFS, Klinkhamer PGL, Choi YH. Plant latex, from ecological interests to bioactive chemical resources. Planta Med 2019; 85(11-12): 856-868. http://dx.doi.org/10.1055/a-0923-8215. PMid:31137048.

Acevedo-Ramírez PMC, Hallal-Calleros C, Flores-Pérez I, Alba-Hurtado F, Mendoza-Garfías MB, Castro del Campo N, et al. Anthelmintic effect and tissue alterations induced in vitro by hydrolysable tannins on the adult stage of the gastrointestinal nematode Haemonchus contortus. Vet Parasitol 2019; 266: 1-6. http://dx.doi.org/10.1016/j.vetpar.2018.12.008. PMid:30736941.

Acharya J, Hildreth MB, Reese RN. In vitro screening of forty medicinal plant extracts from the United States Northern Great Plains for anthelmintic activity against Haemonchus contortus. Vet Parasitol 2014; 201(1-2): 75-81. http://dx.doi.org/10.1016/j. vetpar.2014.01.008. PMid:24548703.

Alowanou GG, Olounladé PA, Akouèdegni GC, Faihun AML, Koudandé DO, Hounzangbé-Adoté S. In vitro anthelmintic effects of Bridelia ferruginea, Combretum glutinosum, and Mitragyna inermis leaf extracts on Haemonchus contortus, an abomasal nematode of small ruminants. Parasitol Res 2019; 118(4): 1215-1223. http://dx.doi.org/10.1007/s00436-019-06262-5. PMid:30848351.

Al-Qarawi AA, Mahmoud OM, Sobaih MA, Haroun EM, Adam SEI. A preliminary study on the anthelmintic activity of Calotropis procera latex against Haemonchus contortus infection in Najdi sheep. Vet Res Commun 2001; 25(1): 61-70. http://dx.doi. org/10.1023/A:1026762002947. PMid:11214673.

Amorin A, Borba HR, Carauta JP, Lopes D, Kaplan MA. Anthelmintic activity of the latex of Ficus species.J Ethnopharmacol 1999; 64(3): 255-258. http://dx.doi.org/10.1016/S0378-8741(98)00139-1. PMid:10363841.

André WPP, Cavalcante GS, Ribeiro WLC, Santos JML, Macedo ITF, Paula HCB, et al. Anthelmintic effect of thymol and thymol acetate on sheep gastrointestinal nematodes and their toxicity in mice. Rev Bras Parasitol Vet 2017; 26(3): 323-330. http://dx.doi. org/10.1590/s1984-29612017056. PMid:28977246.

André WPP, Ribeiro WLC, Cavalcante GS, Santos JML, Macedo ITF, Paula HCB, et al. Comparative efficacy and toxic effects of carvacryl acetate and carvacrol on sheep gastrointestinal nematodes and mice. Vet Parasitol 2016; 218: 52-58. http://dx.doi. org/10.1016/j.vetpar.2016.01.001. PMid:26872928.

Anya AO. The structure and chemical composition of the nematode cuticle. Observations on some oxyurids and Ascaris. Parasitology 1966; 56(1): 179-198. http://dx.doi.org/10.1017/S0031182000071201. PMid:5912229.

Araújo-Filho JV, Ribeiro WLC, André WPP, Cavalcante GS, Guerra MCM, Muniz CR, et al. Effects of Eucalyptus citriodora essential oil and its major component, citronellal, on Haemonchus contortus isolates susceptible and resistant to synthetic anthelmintics. Ind Crops Prod 2018; 124: 294-299. http://dx.doi.org/10.1016/j.indcrop.2018.07.059.

Araújo-Filho JV, Ribeiro WLC, André WPP, Cavalcante GS, Rios TT, Schwinden GM, et al. Anthelmintic activity of Eucalyptus citriodora essential oil and its major component, citronellal, on sheep gastrointestinal nematodes. Rev Bras Parasitol Vet 2019; 28(4): 644651. http://dx.doi.org/10.1590/s1984-29612019090. PMid:31800886.

Behnke JM, Buttle DJ, Stepek G, Lowe A, Duce IR. Developing novel anthelmintics from plant cysteine proteinases. Parasit Vectors 2008; 1(1): 29. http://dx.doi.org/10.1186/1756-3305-1-29. PMid:18761736.

Belemlilga MB, Traoré A, Ouédraogo S, Kaboré A, Tamboura HH, Guissou IP. Anthelmintic activity of Saba senegalensis (A.DC.) Pichon (Apocynaceae) extract against adult worms and eggs of Haemonchus contortus. Asian Pac J Trop Biomed 2016; 6(11): 945949. http://dx.doi.org/10.1016/j.apjtb.2016.07.015.

Bradford MM. A Rapid and Sensitive Method for the Quantitation Microgram Quantities of Protein Utilizing the Principle of Protein-Dye Binding. Anal Biochem 1976; 72(1-2): 248-254. http://dx.doi.org/10.1016/0003-2697(76)90527-3. PMid:942051.

Brunet S, Fourquaux I, Hoste $\mathrm{H}$. Ultrastructural changes in the third-stage, infective larvae of ruminant nematodes treated with sainfoin (Onobrychis viciifolia) extract. Parasitol Int 2011; 60(4): 419-424. http://dx.doi.org/10.1016/j.parint.2010.09.011. PMid:21787880.

Cavalcante GS, Morais SM, Andre WPP, Ribeiro WLC, Rodrigues ALM, Lira FCML, et al. Chemical composition and in vitro activity of Calotropis procera (Ait.) latex on Haemonchus contortus. Vet Parasitol 2016; 226: 22-25. http://dx.doi.org/10.1016/j. vetpar.2016.06.012. PMid:27514877. 
Chundattu SJ, Agrawal VK, Ganesh N. Phytochemical investigation of Calotropis procera. Arab J Chem 2016; 9: S230-S234. http:// dx.doi.org/10.1016/j.arabjc.2011.03.011.

Cortes-Morales JA, Olmedo-Juárez A, Trejo-Tapia G, González-Cortazar M, Domínguez-Mendoza BE, Mendoza-de Gives P, et al. In vitro ovicidal activity of Baccharis conferta Kunth against Haemonchus contortus. Exp Parasito/ 2019; 197: 20-28. http://dx.doi. org/10.1016/j.exppara.2019.01.003. PMid:30633914.

Dewan S, Sangraula H, Kumar VL. Preliminary studies on the analgesic activity of latex of Calotropris procera. J Ethnopharmacol 2000; 73(1-2): 307-311. http://dx.doi.org/10.1016/S0378-8741(00)00272-5. PMid:11025170.

El Sheikh HA, Ali BH, Homeida AM, Hassan T, Idris OF, Hapke HJ. The activities of drug-metabolizing enzymes in goats treated orally with the latex of Calotropis procera and the influence of dieldrin pretreatment. J Comp Pathol 1991; 104(3): 257-268. http:// dx.doi.org/10.1016/S0021-9975(08)80038-2. PMid:2061426.

Elandalousi RB, Akkari H, B'chir F, Gharbi M, Mhadhbi M, Awadi S, et al. Thymus capitatus from Tunisian arid zone: chemical composition and in vitro anthelmintic effects on Haemonchus contortus. Vet Parasitol 2013; 197(1-2): 374-378. http://dx.doi. org/10.1016/j.vetpar.2013.05.016. PMid:23768565.

Freitas CDT, Nogueira FCS, Vasconcelos IM, Oliveira JTA, Domont GB, Ramos MV. Osmotin purified from the latex of Calotropis procera: biochemical characterization, biological activity and role in plant defense. Plant Physiol Biochem 2011; 49(7): 738-743. http://dx.doi.org/10.1016/j.plaphy.2011.01.027. PMid:21334906.

Freitas CDT, Oliveira JS, Miranda MRA, Macedo NMR, Sales MP, Villas-Boas LA, et al. Enzymatic activities and protein profile of latex from Calotropis procera. Plant Physiol Biochem 2007; 45(10-11): 781-789. http://dx.doi.org/10.1016/j.plaphy.2007.07.020. PMid:17888673.

Hassan MHA, Ismail MA, Moharram AM, Shoreit AAM. Phytochemical and antimicrobial of latex serum of Calotropis procera and its silver nanoparticles against some reference pathogenic strains. J Ecol Health Environ 2017; 5(3): 65-75. http://dx.doi. org/10.18576/jehe/050301.

Hoste $\mathrm{H}$, Torres-Acosta JFJ. Non chemical control of helminths in ruminants: adapting solutions for changing worms in a changing world. Vet Parasitol 2011; 180(1-2): 144-154. http://dx.doi.org/10.1016/j.vetpar.2011.05.035. PMid:21705144.

Iqbal Z, Lateef M, Jabbar A, Muhammad G, Khan MN. Anthelmintic activity of Calotropis procera (Ait.) Ait. F. flowers in sheep. J Ethnopharmaco/ 2005; 102(2): 256-261. http://dx.doi.org/10.1016/j.jep.2005.06.022. PMid:16085379.

Jiao Y, Preston S, Garcia-Bustos JF, Baell JB, Ventura S, Le T, et al. Tetrahydroquinoxalines induce a lethal evisceration phenotype in Haemonchus contortus in vitro. Int J Parasitol Drugs Drug Resist 2019; 9: 59-71. http://dx.doi.org/10.1016/j.jpddr.2018.12.007. PMid:30690282.

Khasawneh MA, Elwy HM, Fawzi NM, Hamza AA, Chevidenkandy AR, Hassan AH. Antioxidant activity, lipoxygenase inhibitory effect and polyphenolic compounds from Calotropis procera (Ait.) R. Br. Res J Phytochem 2011; 5(2): 80-88. http://dx.doi.org/10.3923/ rjphyto.2011.80.88.

Kore PS, Virk A, Peste A. Evaluation of in vitro anthelmintic potential of quercetin against Pheretima posthuma. J Pharm Res 2018; 12: $974-976$.

Kumar VL, Shivkar YM. In vivo and in vitro effect of latex of Calotropis procera on gastrointestinal smooth muscles.J Ethnopharmacol 2004; 93(2-3): 377-379. http://dx.doi.org/10.1016/j.jep.2004.04.013. PMid:15234780.

Lanusse C, Canton C, Virkel G, Alvarez L, Costa-Junior L, Lifschitz A. Strategies to optimize the efficacy of anthelmintic drugs in ruminants. Trends Parasitol 2018; 34(8): 664-682. http://dx.doi.org/10.1016/j.pt.2018.05.005. PMid:29960843.

Macedo ITF, Bevilaqua CML, Oliveira LMB, Camurça-Vasconcelos ALF, Morais SM, Machado LKA, et al. In vitro activity of Lantana camara, Alpinia zerumbet, Mentha villosa and Tagetes minuta decoctions on Haemonchus contortus eggs and larvae. Vet Parasitol 2012; 190(3-4): 504-509. http://dx.doi.org/10.1016/j.vetpar.2012.07.001. PMid:22835864.

Mahmoud OM, Adam SEI, Tartour G. The effects of Calotropis procera on small ruminants: II. Effects of administration of the latex to sheep and goats. J Comp Patho/ 1979; 89(2): 251-263. http://dx.doi.org/10.1016/0021-9975(79)90064-1. PMid:457944.

Martínez-Ortíz-de-Montellano C, Arroyo-López C, Fourquaux I, Torres-Acosta JFJ, Sandoval-Castro CA, Hoste H. Scanning electron microscopy of Haemonchus contortus exposed to tannin-rich plants under in vivo and in vitro conditions. Exp Parasito/ 2013; 133(3): 281-286. http://dx.doi.org/10.1016/j.exppara.2012.11.024. PMid:23246590.

Matos FJA. Introdução a fitoquímica experimental. Fortaleza: Edições UFC; 1988.

Mohamed NH, Liu M, Abdel-Mageed WM, Alwahibi LH, Dai H, Ismail AM, et al. Cytotoxic cardenolides from the latex of Calotropis procera. Bioorg Med Chem Lett 2015; 25(20): 4615-4620. http://dx.doi.org/10.1016/j.bmcl.2015.08.044. PMid:26323871.

Mottier L, Alvarez L, Ceballos L, Lanusse C. Drug transport mechanisms in helminth parasites: passive diffusion of benzimidazole anthelmintics. Exp Parasitol 2006; 113(1): 49-57. http://dx.doi.org/10.1016/j.exppara.2005.12.004. PMid:16430886. 
Mottier ML, Alvarez LI, Pis MA, Lanusse CE. Transtegumental diffusion of benzimidazole anthelmintics into Moniezia benedeni: correlation with their octanol-water partition coefficients. Exp Parasitol 2003; 103(1-2): 1-7. http://dx.doi.org/10.1016/S00144894(03)00060-2. PMid:12810040.

Murti Y, Sharma S, Mishra P. In vitro Anthelminthic activity of Calotropis procera (Ait.) R. Br. Leaves. Asian J Pharm Clin Res 2015; 8(6): 188-190.

Niciura SCM, Cruvinel GG, Moraes CV, Chagas ACS, Esteves SN, Benavides MV, et al. In vivo selection for Haemonchus contortus resistance to monepantel.J Helminthol 2019; 94: e46. http://dx.doi.org/10.1017/S0022149X19000221. PMid:30880654.

Page AP, Stepek G, Winter AD, Pertab D. Enzymology of the nematode cuticle: A potential drug target? Int J Parasitol Drugs Drug Resist 2014; 4(2): 133-141. http://dx.doi.org/10.1016/j.ijpddr.2014.05.003. PMid:25057463.

Patel M, Ganeshpurkar A, Bansal D, Dubey N. Experimental evaluation of anthelmintic effect of Gallic Acid. Pharmacogn Commun 2015; 5(2): 145-147. http://dx.doi.org/10.5530/pc.2015.2.6.

Ramos MV, Araújo ES, Jucá TL, Monteiro-Moreira ACO, Vasconcelos IM, Moreira RA, et al. New insights into the complex mixture of latex cysteine peptidases in Calotropis procera. Int J Biol Macromol 2013; 58: 211-219. http://dx.doi.org/10.1016/j. ijbiomac.2013.04.001. PMid:23583491.

Ramos MV, Demarco D, Costa Souza IC, Freitas CDT. Laticifers, latex, and their role in plant defense. Trends Plant Sci 2019; 24(6): 553-567. http://dx.doi.org/10.1016/j.tplants.2019.03.006. PMid:30979674.

Ranjit PM, Eswara RG, Krishnapriya M, Nagalakshimi V, Silpa P, Anjali M. An overwiew of phytochemical and pharmacological activities of Calotropis procera. FS J Pharm Res 2012; 1(2): 18-25.

Ribeiro WLC, Andre WPP, Cavalcante GS, Araújo-Filho JV, Santos JML, Macedo ITF, et al. Effects of Spigelia anthelmia decoction on sheep gastrointestinal nematodes. Small Rumin Res 2017; 153: 146-152. http://dx.doi.org/10.1016/j.smallrumres.2017.06.001.

Ribeiro WLC, Camurça-Vasconcelos ALF, Macedo ITF, Santos JML, Araújo-Filho JV, Ribeiro JC, et al. In vitro effects of Eucalyptus staigeriana nanoemulsion on Haemonchus contortus and toxicity in rodents. Vet Parasitol 2015; 212(3-4): 444-447. http://dx.doi. org/10.1016/j.vetpar.2015.07.019. PMid:26233731.

Ribeiro WLC, Macedo ITF, Santos JML, Oliveira EF, Camurça-Vasconcelos ALF, Paula HCB, et al. Activity of chitosan-encapsulated Eucalyptus staigeriana essential oil on Haemonchus contortus. Exp Parasitol 2013; 135(1): 24-29. http://dx.doi.org/10.1016/j. exppara.2013.05.014. PMid:23748159.

Rothwell JT, Sangster NC. The effects of closantel treatment on the ultrastructure of Haemonchus contortus. Int J Parasito/ 1996; 26(1): 49-57. http://dx.doi.org/10.1016/0020-7519(95)00087-9. PMid:9198596.

Sant'anna V, Vommaro RC, Souza W. Caenorhabditis elegans as a model for the screening of anthelminthic compounds: ultrastructural study of the effects of albendazole. Exp Parasito/ 2013; 135(1): 1-8. http://dx.doi.org/10.1016/j.exppara.2013.05.011. PMid:23727123.

Santos JML, Vasconcelos JF, Frota GA, Ribeiro WLC, André WPP, Vieira LS, et al. Haemonchus contortus $\beta$-tubulin isotype 1 gene F200Y and F167Y SNPs are both selected by ivermectin and oxfendazole treatments with differing impacts on anthelmintic resistance. Vet Parasito/ 2017; 248: 90-95. http://dx.doi.org/10.1016/j.vetpar.2017.11.003. PMid:29173548.

Silva A, Morais SM, Marques MMM, Lima DM, Santos SCG, Almeida RR, et al. Antiviral activities of extracts and phenolic components of two Spondias species against dengue virus. J Venom Anim Toxins Incl Trop Dis 2011; 17(4): 406-413. http://dx.doi.org/10.1590/ S1678-91992011000400007.

Singh AN, Shukla AK, Jagannadham MV, Dubey VK. Purification of a novel cysteine protease, procerain B, from Calotropis procera with distinct characteristics compared to procerain. Process Biochem 2010; 45(3): 399-406. http://dx.doi.org/10.1016/j. procbio.2009.10.014.

Ueno H, Gonçalves P. Manual para diagnóstico das helmintoses de ruminantes. Tokyo: Japan International Cooperation Agency; 1998.

Upadhyay B, Singh KP, Kumar A. Ethno-veterinary uses and informants consensus factor of medicinal plants of Sariska region, Rajasthan, India.J Ethnopharmaco/ 2011; 133(1): 14-25. http://dx.doi.org/10.1016/j.jep.2010.08.054. PMid:20817085.

Vila-Nova NS, Morais SM, Falcão MJC, Bevilaqua CML, Rondon FCM, Wilson ME, et al. Leishmanicidal and cholinesterase inhibiting activities of phenolic compounds of Dimorphandra gardneriana and Platymiscium floribundum, native plants from Caatinga biome. Pesq Vet Bras 2012; 32(11): 1164-1168. http://dx.doi.org/10.1590/S0100-736X2012001100015.

Zhu L, Dai J, Yang L, Qiu J. Anthelmintic activity of Arisaema franchetianum and Arisaema lobatum essential oils against Haemonchus contortus. J Ethnopharmacol 2013; 148(1): 311-316. http://dx.doi.org/10.1016/j.jep.2013.04.034. PMid:23624115. 